\title{
6. UNDERWAY GEOPHYSICAL DATA FROM DEEP SEA DRILLING PROJECT LEG 64: NAVIGATION, BATHYMETRY, MAGNETICS, AND SEISMIC PROFILES ${ }^{1}$
}

\author{
Joseph R. Curray, David G. Moore, and Stuart M. Smith, Scripps Institution of Oceanography, La Jolla, California \\ and \\ Thomas E. Chase, U. S. Geological Survey, Menlo Park, California
}

\section{INTRODUCTION}

Leg 64, devoted to drilling in the Gulf of California, began in Mazatlán on December 1, 1978, and ended in San Pedro, California, on January 14. Glomar Challenger logged 1162 nautical miles of steaming within the Gulf on this leg (Fig. 1), during most of which underway geophysical data were collected, including bathymetry, magnetic data, and seismic-reflection data. These data were recorded on the ship under the supervision of Laboratory Officer D. Cameron and electronic technician Harry Sprink. Data processing after the cruise was done by the Geological Data Center of Scripps Institution of Oceanography and is referenced as GDC Cruise I.D. No. 124. The following data are available from the Information Handling Group, Deep Sea Drilling Project, A-031, Scripps Institution of Oceanography, La Jolla, California 92093:

1) Profiles of depths and magnetic anomalies plotted versus distance. Dates (day/month) and positions of major course changes $\left(>30^{\circ}\right)$ are annotated. Sections of track having sub-bottom profiler (airgun) records are identified by a solid black line along the bottom of the profile (Fig. 2).

2) Navigation listings of times and positions of course and speed changes, fixes, and drift velocity.

3) Depth-compilation plots, in meters (assumed sound velocity $1500 \mathrm{~m} / \mathrm{s}$ ), at approximately 1 -mile spacing, plotted at 4 in./degree, with standard Defense Mapping Agency Hydrographic Center Office B. C. Series boundaries.

4) Plots of magnetic profiles along track, map scale $=1.2 \mathrm{in} . /$ degree; anomaly scale $=1000$ gamma $/$ in.; from values retrieved at approximately 1-mile spacing and regional field removed using the 1975 IGRF.

5) Individual time series files of navigation, depth, and magnetics, as well as merged file in MGD $77 \mathrm{ex}-$ change format, on magnetic tape.

6) S.I.O. Sample Index-list of drill sites and beginning and end times and positions of all underway records collected on the cruise leg.

7) Microfilm or Xerox copies of: (a) echo sounder record $(12 \mathrm{kHz}, 3.5 \mathrm{kHz})$; (b) sub-bottom profiler records (airgun).

\footnotetext{
${ }^{1}$ Curray, J. R., Moore, D. G., et al., Init. Repts. DSDP, 64: Washington (U.S. Govt. Printing Office).
}

\section{METHODS}

\section{Navigation}

Satellite fixes and course and speed changes were encoded aboard the Challenger from data given in the underway geophysical log. The data were keypunched on shore and put through a navigational smoothing program, edited on the basis of reasonable ship-drift velocities, and a deck of corrected navigation points punched out for later merging with the depth and magnetic data. The table in Chart 1 (back pocket, this volume, $\mathrm{Pt}$. 1) contains time, position, satellite-fixes, distance, course, speed, and drift data. The ship's track, with day and hour ticks in GMT, is shown in Figure 1 and in a simplified manner in back pocket Chart 1 .

Depth

The depths, scaled from echo sounders $(1500 \mathrm{~m} / \mathrm{s}$ calibrated sound velocity), were recorded at sea in the underway geophysical log book at 5-minute intervals. The depths were keypunched on shore and edited by comparison with the original analog records. The bathymetric profiles obtained are shown on Figure 2, where they are keyed to both nautical miles (n.m.) from Mazatlán and day and hour time ticks.

\section{Magnetics}

The magnetics scaled from analog records produced on the Geometrics Magnetometer were recorded at sea in the underway geophysical $\log$ book in gammas at 5 -minute intervals. The magnetics were keypunched on shore, put through a profile program, and edited by comparison to the original analog records. These magnetic profiles are shown in Figure 2, where they are keyed to both n.m. from Mazatlán and day and hour ticks.

\section{Seismic Profiles}

The energy sources were Bolt airguns; generally 20 and $120 \mathrm{cu}$. in. guns were streamed as a pair. Returns were recorded on two EPC recorders, with appropriate trigger delays depending on water depth. One recorder was set for a 5-s sweep, with a band-pass filter setting of 20 to $80 \mathrm{~Hz}$. The other recorder was generally set for a 2-s sweep, with a band-pass filter setting of 80 to $160 \mathrm{~Hz}$. All records (Seismic and 3.5 $\mathrm{kHz}$ ) are reproduced in Profiles 1-2 (back pocket, this volume, Pt. 1).

\section{5-kHz Profiles}

3.5-kHz records were recorded on an EPC recorder, using the hullmounted transducer of Glomar Challenger. Whenever possible, the shortest possible ping length was utilized to improve resolution within the sub-bottom, and whenever possible, appropriate trigger delays were used to keep the returning echoes centered on the recorder.

\section{Sonobuoy Wide-Angle Reflection and Refraction Measurements}

During the leg, three expendable sonobuoy wide-angle reflection and refraction runs were attempted at Sites 474, 477, and 478. Fairfield expendable sonobuoys were utilized, generally on channel $10 \mathrm{~L}$. The runs at Sites $\mathbf{4 7 4}$ and $\mathbf{4 7 8}$ were made while the ship was on site by permitting the sonobuoy to drift away from the ship, aided by the sail area of a plastic XBT case. A single 120-cu. in. airgun was fired at 10-s intervals, and sweeps of 5 and $10 \mathrm{~s}$ were made on the two EPC recorders, with band-pass settings of 2 to $62 \mathrm{~Hz}$. Useful wide-angle reflection was obtained from each of these, and useful refracted arrivals 


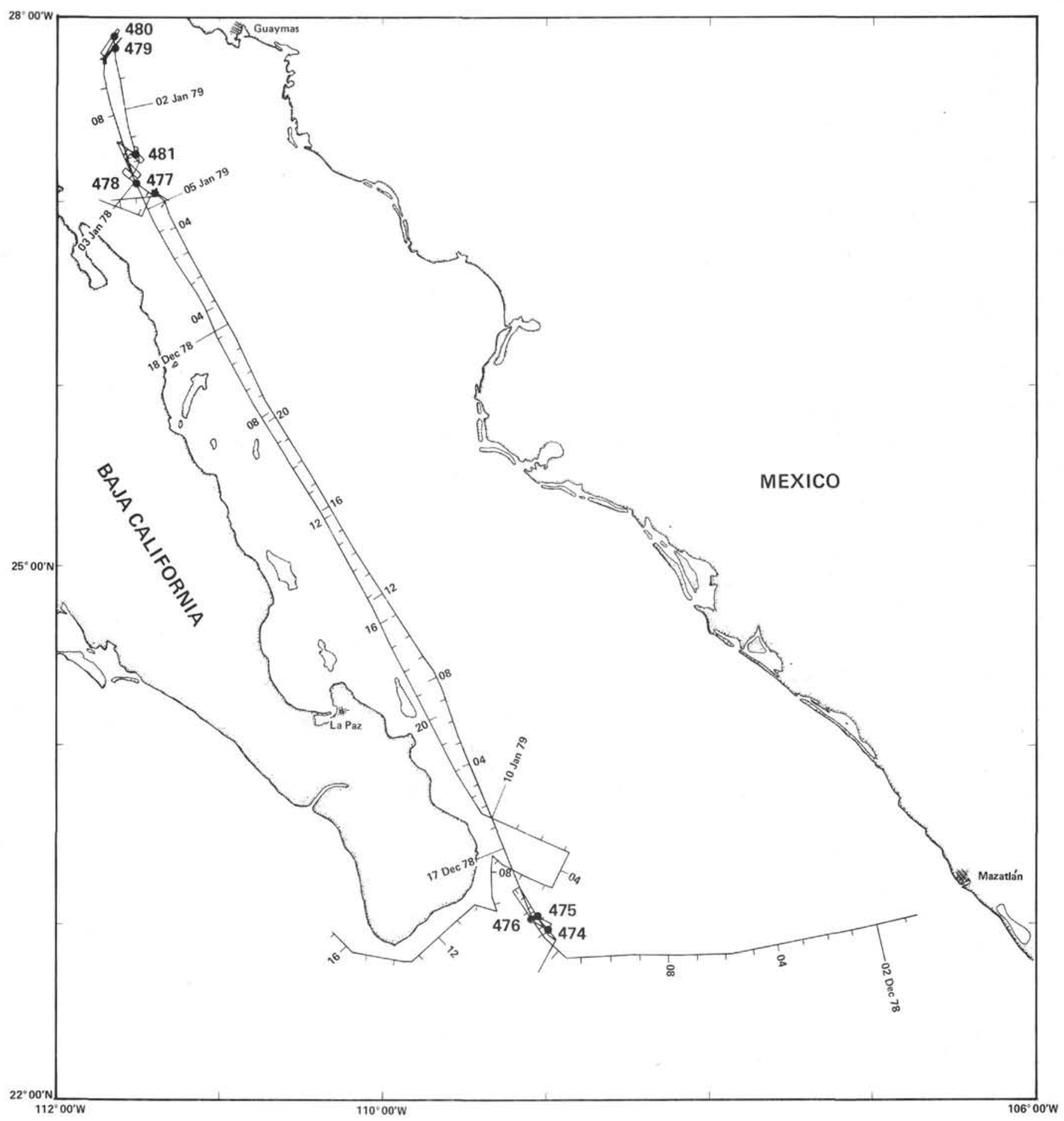

Figure 1. Track of Leg 64 within the Gulf of California, with 1-hour time and date ticks and drilling sites.

were obtained at Station 474 . These results are utilized in the respective site chapters as velocity information. The sonobuoy run at Site 477 was an underway run made while surveying toward Hole $477 \mathrm{~A}$, but no useable results were obtained.

\section{RESULTS AND DISCUSSION}

Airgun seismic-reflection records and $3.5-\mathrm{kHz}$ records in the vicinity of the drilling sites were utilized in the site chapters for correlation with drilling results. In some cases, other single-channel or multichannel records from site survey cruises were also utilized in those discussions. These records have also been utilized in the synthesis papers on structure and tectonics of the three drilling areas and for preparation of the isopach map of the southern Gulf (Figure 8, in Einsele and Niemitz, this volume, Pt. 2). No further description or discussion are therefore necessary in this chapter. 

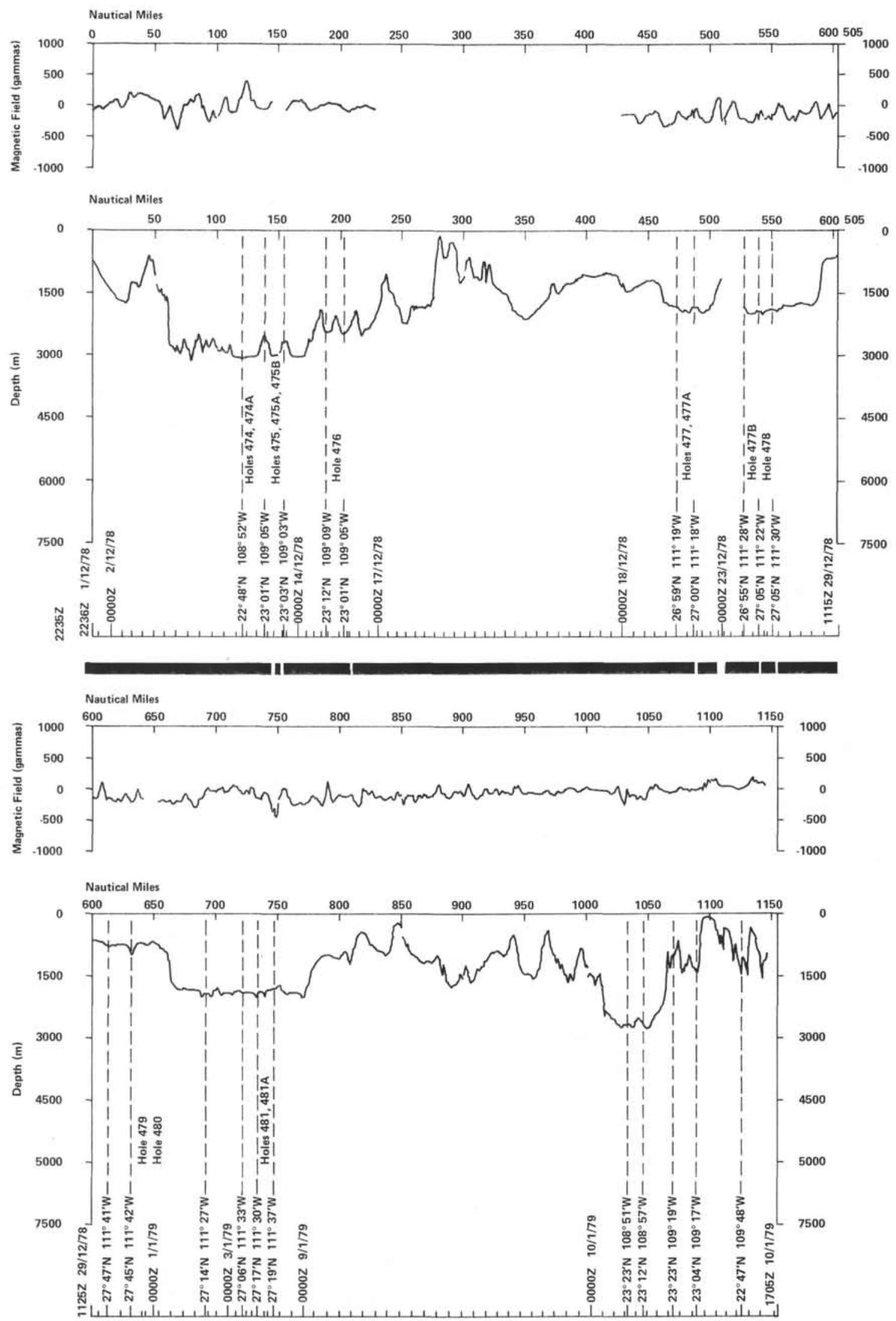

Figure 2. Profiles of bathymetry and magnetics plotted against time and n.m. from Mazatlán. Heavy line at bottom shows locations of airgun seismic profiles shown in back pocket Profile 1 . 